\title{
On how RE Teachers Address the Sometimes Conflicting Tasks of Conveying Fundamental Values and Facilitating Critical Thinking
}

\author{
By Niclas Lindström ${ }^{*} \&$ Lars Samuelsson ${ }^{ \pm}$
}

\begin{abstract}
Teachers in the non-confessional Swedish subject religious education have conflicting responsibilities to convey values and facilitate critical thinking. The research regarding these responsibilities has often been considered a theoretical problem and the discussion has concerned theoretical solutions. However, the problem is not only theoretical. It is in fact also a practical problem that many teachers frequently encounter. The overall aim of this paper is thus to draw attention to these conflicting responsibilities as a practical problem that teachers face and are expected to solve in their pedagogical practices. In line with this aim, a number of qualitative research interviews were conducted with experienced religious education teachers, who are considered to have a particular responsibility for moral education in the Swedish school system. The purpose of the interviews was to investigate how they relate to their sometimes conflicting responsibilities and consequently make an empirically informed contribution to the debate. This is an important task since there are no official guidelines on how teachers are to balance these responsibilities in their pedagogical practices.
\end{abstract}

Keywords: moral education, paradox of moral education, religious education, controversial issues, ethics.

\section{Introduction}

A recurring idea, among practitioners and researchers, is that "teaching is an activity in which moral issues arise inevitably" (O'Hear, 1998, p. 14; see also: Hansen, 2001; Bullough, 2011; Campbell, 2013). Some, like Jackson, Boostrom and Hansen (1993), have even stated that "all that can be seen and heard in classrooms" (p. 43) can be of moral significance, including "events, actions and even aspects of the physical environment" (p. 2). Yet, they often seem to be divided on how teachers ought to treat ideals, norms and values in their pedagogical practices.

The educational philosopher Peters (1998) has articulated what can be interpreted as one reason for the disagreements concerning moral education as follows: "On the one hand there is an emphasis on habit, tradition and being properly brought up; on the other hand there is an emphasis on intellectual training, and on the development of critical thought and choice" (p. 27). This indicates that teachers are expected to balance different roles, as conveyers of values and facilitators of critical thinking, with conflicting educational aims: that the pupils should become eligible democratic citizens and independent rational

\footnotetext{
*Associate Professor, Umeå University, Sweden.

${ }^{ \pm}$Associate Professor, Umeå University, Sweden.
} 
individuals. At the same time teachers should avoid being authoritarian or indoctrinating children. Moreover, there is no prevailing consensus concerning if any normative theory is correct and in that case which it would be (O'Hear, 1998, p. 15; Hand, 2014, p. 521). Thus, moral and ethics education can be considered controversial issues, as Hirst and White (1998) put it, not only because they concern "contested areas in philosophy" but also because of continuing "disagreement over their possible aims" and "the considerable debate over these" (p. 2).

The conflicting responsibilities to convey values and facilitate critical thinking has often been considered a theoretical problem and the discussion has concerned theoretical solutions (e.g., Peters, 1998, pp. 38-39; Gardener, 1981, p. 65; Gardener, 1985; O'Hear, 1998). However, the problem is not only theoretical. As will be elaborated below, it is in fact a real practical problem that many teachers frequently encounter. The overall aim of this paper is thus to draw attention to the conflicting responsibilities as a practical problem that teachers face and are expected to solve in their pedagogical practices. In line with this aim, a number of qualitative research interviews were conducted with experienced religious education (RE) teachers, who are considered to have a particular responsibility for moral education in the Swedish school system (Almén, Furenhed, Hartman, \& Skogar 2000; Hartman, 2008; Larsson, 2009; Franck \& Löfstedt, 2015) ${ }^{1}$. The purpose of the interviews was to investigate how they relate to their conflicting responsibilities and consequently make an empirically informed contribution to the debate. This is an important task since there are no official guidelines on how teachers are to balance these responsibilities in their pedagogical practices.

\section{The Paradox of Moral Education}

The conflicting responsibilities teachers frequently face, of conveying values and facilitating critical thinking, is one of several related problems that educational philosophers sometimes refer to as the paradox of moral education (see for example, Gardener, 1981, p. 65; Aristotle, 1977, p. 635; Aristotle, 1982, p. 629835; Taylor, 1982, p. 1; Kristjánsson, 2006, p. 102; Curren, 2014, p. 485). Influential educational philosophers have related to these problems in several different ways. Some have focused on the psychological aspect of the paradox and discussed how it is possible to develop individuals to behave rationally from an age where they are incapable to do that (Peters, 1998, p. 32). Others have focused on the moral aspect of the paradox, considering the conflicting responsibilities, which is the point of departure for this study (O'Hear, 1998, p. 15). There are several recurring perspectives in the literature on how to solve the paradox which, in this context, can be divided in three broad approaches to moral education.

(1) Some argue that teachers should lead by example and thereby help their pupils to form good habits and develop desirable character traits e.g., "integrity, patience, tolerance, honesty, courtesy, reliability, considerateness, [and] good will"

${ }^{1}$ In the Swedish school system, religious education is a non-confessional subject (SNAE, 2011). 
(Carr, 1983, p. 48). This is often combined with an emphasis on the ability to respond emotionally to others as a part of a social group which is characteristic of a character-based approach (see for example, Aristotle, 1982, pp. 111-115; Kristjánsson, 2006, p. 104; Curren, 2010, p. 488; Carr, 2015, p. 430, p. 444). Instead of considering moral education only as an exercise of rational thinking to reach justified decisions, where it is hard to establish if and how they are translated into action, teachers should concentrate on their pupils' moral growth and personal maturity (see Carr, 1983, pp. 45-50; Carr, 1996, p. 355; Carr, 2007, pp. 369-373)2.

(2) Others claim that teachers should challenge their pupils with moral dilemmas on a level above their ability and thereby contribute to their capacity to reason and develop cognitively (Kohlberg, 1966, p. 24). Another alternative is, for instance, that the teacher asks the pupils questions and follows up their responses, in order to unveil the principles on which they base their judgements (Surprenant, 2010, p. 170). This is often combined with an emphasis on the capability to think rationally in order to become autonomous individuals, which is characteristic of a reason-based approach (Kohlberg, 1966, p. 17; Surprenant, 2010, p. 172). Instead of considering moral education as habituation, which is regarded as ineffective and involves a risk of indoctrination, teachers should concentrate on pupils rational thinking in order to facilitate their cognitive development into autonomous adults (Kohlberg, 1966, pp. 3, 14; see also Surprenant, 2010, pp. 169-174).

(3) Yet others argue that the division between habit and rational thinking has been overemphasized in the current debate. According to this view it may even be necessary to form habits (e.g., of giving reasons) in order to intellectually understand how and why it is desirable to develop certain character traits, which is characteristic of an integrated approach of moral education (see for example, Aristotle, 1982, pp. 75-79; Peters, 1998, pp. 34-37; Carr \& Steutel, 1999, p. 249; Kristjánsson, 2006, p. 120; Curren, 2014, p. 496; Carr, 2015, p. 444; Kristjánsson, 2015, pp. 90-103). Some take the argument even one step further and suggest that it is possible to use art or literature in order to develop habits of thought, as for instance an attention to others as human beings, which can evoke compassion or sympathy that contributes to our moral awareness and autonomy (O'Hear, 1998, pp. 22-26; see also Murdoch, 2001, pp. 84-85; Nussbaum, 1992, p. 84). In other words, teachers should concentrate on the pupils' habituation in a social community in order to facilitate individuation, autonomy and critical thinking.

A short presentation of previous research inevitably leaves out some details, complexities and variations. However, these approaches to moral education represent various interpretations of teachers' responsibilities which can contribute to competing solutions of the paradox of moral education. What most of the alternatives have in common is that they, as Peters (1998) put it, try to "resolve the theoretical paradox of moral education in a theoretical manner" (p. 39). This is however only one part of the problem. According to the Swedish Education Act (2010:800, 4 §) and the Curriculum for the Upper Secondary School in Sweden (SNAE, 2013), all teachers in the Swedish education system are expected to

\footnotetext{
${ }^{2}$ Proponents of this view often use a combination of arguments in order to solve the paradox of moral education and can show tendencies towards an integrated or eclectic approach to moral education.
} 
convey a set of fundamental values, in order to form the pupils into democratic citizens: "Each and everyone working in the school should... encourage respect for the intrinsic value of each person and the environment we all share. [...] In accordance with the ethics borne by Christian tradition and Western humanism, this is to be achieved by nurturing in the individual, a sense of justice, generosity, tolerance and responsibility" (p. 4). In addition to this, RE teachers have a responsibility to contribute to the pupils' ability to "use ethical concepts, ethical theories and models" and facilitate "critical thinking" (SNAE, 2011, p. 137). This makes the paradox of moral education into a practical problem that teachers face. An overview of previous research can, which we will see later, have heuristic value when analysing an empirical material (see for example, Haydon 2010, p. $174)^{3}$.

\section{Methodology}

In order to investigate how RE teachers relate to the conflicting responsibilities to convey a set of fundamental values and contribute to the pupils' abilities to critically examine ideals, norms and values, a series of qualitative research interviews were conducted. The participants were seven licenced RE teachers with 9-32 years of experience in the profession (Teacher 1-7). The teachers who took part in the interviews were briefed about the general purpose of the study and invited to participate voluntarily under the condition that they could discontinue at any time. They were informed, verbally and in writing, that their answers would be anonymized, treated as confidential, and used for research purposes only. During the study no personal data were stored and no questions of a sensitive character were posed, e.g., concerning political, philosophical or religious conviction. The interviews were carried out at the schools where the teachers work and at two occasions at Umeå University. In this way the study was designed to ensure compliance to the general research ethical principles of informed consent, anonymity, confidentiality and precautious use of collected information (Swedish Research Council, 2017). The project was approved by the Swedish Ethical Review Authority.

The interviews were conducted using a protocol with open-ended questions on three overarching themes of how the RE teachers: (1) convey ideals, norms and values to their pupils, (2) contribute to their development of critical thinking and (3) handle situations in which these responsibilities conflict with each other. In addition to these themes supplementary questions were asked in order to get fuller descriptions of how the RE teachers relate to the responsibilities and they were encouraged to illustrate with examples from their pedagogical practices (see Yin, 1994; Kvale, 2007; Bryman, 2008). All of the interviews were audio-recorded and

\footnotetext{
${ }^{3}$ Some researchers even acknowledge the difficulty of using one of these perspectives to understand the complexities of moral life and propose an eclectic approach to moral education where elements from several different theories are allowed to coexist (see Haydon, 2010, p. 186; Peters, 1998, p. 37).
} 
transcribed in order to enable further analysis and serve as a background to our upcoming discussion (see Kvale, 2007, pp. 92-97).

In this investigation the different approaches to moral education, which were introduced in the background, are used as analytical tools in order to categorize how the RE teachers relate to the sometimes conflicting responsibilities to mediate fundamental values and contribute to the pupils' abilities to critically examine ideals, norms and values (see Yin, 1994, p. 103). The intention is to apply the model in a context-sensitive manner to give a fair representation of the answers from the interviews. At the same time, it is vital to be open to alternative interpretations of the material, if that proves to be necessary. It is also important to emphasize that the distinctions between different ways of relating to the normative dimensions of teaching are not used in order to determine a correct position. The purpose of this study is rather to give an empirically informed contribution to this ongoing debate.

\section{How RE Teachers Balance the Conflicting Responsibilities}

Analyses of the interviews with the teachers, on how they relate to the conflicting responsibilities to convey and critically examine values, reveal a shared understanding of the subject religious education. All of the teachers who participated in the study expressed that ideals, norms, and values are essential to the study of religion. Yet, there are differences in how the teachers relate to these in their pedagogical practices:

That aspect, tolerance, is what led me to education... to be able to work for a better society where everyone has equal value. This is also a reason why I chose to become a $\mathrm{RE}$ teacher, because it is so apparent, it becomes clear within this context [that everyone is not included or considered to have the same value]. (Teacher 4)

It is the character of the subject... We have to assess everything critically... I want to reach a point where they [the pupils] think for themselves. I cannot tell them what is right or wrong, which opinion to have, or what to think. (Teacher 2)

I would say that, the subject religious education, is about the function of ideals, norms and values in society. I consider morality, ethics, and fundamental values as the core element of religious education. It is what religion actually is all about. (Teacher 5)

One interpretation of these statements is that some teachers emphasize the importance of conveying a set of democratic values to their pupils. Others focus on developing their ability to think critically about ideals, norms, and values. Still others may try to make some form of combination of both as a part of their pedagogical practices. This pattern becomes even more evident in a continued analysis of the empirical material, as we will see, where the participants tend to embrace different approaches to moral education. It is important to note that these teachers' ways of balancing their roles, as conveyers of value and facilitators of 
critical thinking, reflect what previously was labelled character-based, reasonbased, and integrative approaches to moral education, respectively.

\section{Teachers with a Character-Based Approach to Moral Education}

Some of the teachers who participated in the study emphasize the importance of leading by example in order to convey certain values to the pupils. One teacher notes, for instance, that she wants the pupils to "respect other people's faiths... and values" and that "tolerance and respect have to be interwoven as an integrated part of the education" (Teacher 4). Another teacher expresses that "my main task, considering the cultural norms and values, is to convey the golden rule, to do unto others as you would have them do unto you" (Teacher 7). Still another teacher elaborates on a similar point:

I want to convey that we live in a society that rests on a set of common values. These are the values we have agreed upon and that does not mean that everybody agrees with them... I am an important role model, as a grownup, in this regard... to show the pupils how to act to one another in order to make a group or a society work. (Teacher 6)

What the teachers seem to express, is a wish to contribute to their pupils' sense of the values stated in the curriculum, as a part of the process to foster democratic citizens. This is similar to what previously has been labelled a character-based approach to moral education.

The teachers who emphasize the importance of conveying fundamental values also express that they deliberately try to support their pupils in developing an understanding of themselves as a part of a social, cultural and historical context (Teacher 4, Teacher 6). "It is all about understanding what kind of world this is... where we come from and why we behave as we do. It is about understanding oneself... [in order to] understand others..." (Teacher 6). An important objective of moral education is therefore to give the pupils an opportunity to gain critical awareness of their own values, from a national and international perspective, to be able to understand other people and respond to them with empathy or sympathy in a society characterized by increased diversity (Teacher 4 , Teacher 6 ).

The teachers who embrace this approach to moral education do not consider the responsibilities to convey and critically examine values to conflict with each other in the education. In the interviews they give isolated examples of pupils who express sceptical or extreme points of view and question the fundamental values of the curriculum. One teacher describes an encounter with a sceptical pupil. "I was ... working in a project last year about human rights... [One of the pupils] was critical to us addressing this kind of question at all... and to the school system as such" (Teacher 6). Another teacher elaborates on a similar incident: "Of course, it is not amusing, when you have just come back from a visit to Auschwitz, to meet a pupil who questions whether it is possible to burn that many people in an oven" (Teacher 4).

It is illustrative that these examples represent occasions when pupils have questioned the values that are stated in the curriculum and are supposed to be 
conveyed in the education. It is clear that the teachers consider these events as exceptions and to critically assess such values is not something which is imbedded in their function as RE teachers. An interesting feature is that the teachers who emphasize the importance of conveying fundamental values share a scepticism of the analytical tools provided by ethical theory. One of the teachers describes ethical theory as "a little bit rigid" (Teacher 4) and another as "static and hard for the pupils to understand" (Teacher 6). It is possible to interpret the teachers' interest to lead by example, convey values and facilitate the pupils' selfunderstanding in a social, cultural and historical context, as an expression of a character-based approach to moral education.

\section{Teachers with a Reason-Based Approach to Moral Education}

Other teachers who participated in the study emphasize the pupils' ability to think critically, make independent judgements, and justify them to others as an important point of departure for moral education. One of the teachers expresses that the abilities "to question sources" and "view things from different perspectives" are most important in a society characterized by information technology and multiculturalism (Teacher 2). Another teacher stresses that it is important that pupils not only express their own opinions but are aware of "when they are challenging norms" and are capable of "providing reasons for their positions" (Teacher 3). This is similar to what previously has been labelled a reason-based approach to moral education.

One of the teachers describes how he uses examples of conflicting rights, to challenge the pupils, as an integrated part of religious education (Teacher 3 ). This also provides an opportunity to critically assess, for instance, the religious use of the veil in relation to personal integrity and freedom of religion:

The assignments I have constructed, at the moment, are focused on rights. The purpose of my teaching is that they [the pupils] shall understand that... [rights] are supposed to protect the weak and vulnerable [in society]. That the ones who cannot make their voices heard themselves, can be heard through the human rights. This is something which have to be considered when reflecting on, for instance, the rights of the child or parent in relation to a given religious activity... or ethical considerations in general. (Teacher 3 )

In this case, the teacher explains how he uses examples, which involves conflicting rights, to challenge the pupils to think critically, make their own judgements, and justify them to others, as a part of the pedagogical practice.

In order to be able to critically assess dilemmas of conflicting rights and responsibilities the pupils need to be familiar with certain analytical frameworks provided by ethical theory. It is not, according to this teacher, necessary to use classical distinctions of deontology, consequentialism and virtue ethics, but some basic notions are needed to characterize various arguments or positions (Teacher 3). This enables the pupils to become aware of several perspectives of responsibilities and rights and that "one person can use arguments from different traditions" (Teacher 3). It is important that the analysis results in a "critical assessment" and 
an "autonomous decision" where the pupils are able to justify their conclusions (Teacher 3). Hence, the teacher challenges the pupils with dilemmas in order to facilitate their cognitive development into autonomous responsible adults, which is possible to interpret as an expression of a reason-based approach to moral education.

\section{Teachers with an Integrated Approach to Moral Education}

Yet other teachers seem to dissolve a strict division between conveying and critically examining norms and values as they describe their pedagogical practice. As noted above, these teachers consider it necessary to form habits in order to intellectually understand how and why it is desirable to develop certain character traits. This is similar to what previously has been labelled an integrated approach to moral education.

One of the teachers describe how he deliberately use art to raise existential questions regarding the human condition as an introduction to a conversation about the values prevalent in the cultural context and the values that unite all peoples and cultures:

I introduce the course with Sally Mann's pictures of decaying human bodies during the first lesson. How do we, actually, view our existence? This is why death, as a theme, is always present as the basis of the course whether the pupils perceive it or not. In this individualist society everything is motivated in terms of its contribution to maximizing potential and status in existing hierarchies. Even if much is said about equality and power, there is basically an idea of maximizing the level of consumption, whether it is travel, or cars, or anything, really. Then it feels good to have virtue ethics... someone who reminds us of that there are things to work on. There is a humility to that. (Teacher 1)

The use of art is a way of letting go of one's self-centredness and develop a deeper understanding of other people and their points of view, which is necessary in order to think ethically (see for example, Murdoch, 2001, pp. 84-86; O'Hear, 1998 , p. 24). Another teacher notes that discussions of well-chosen dilemmas, which relate to the pupils' everyday lives, can have a similar function (Teacher 5). They can contribute to recognizing that many dilemmas are a part of "the same underlying problem... which we need to address and to which religious education can contribute to a somewhat conscious ethical analysis" (Teacher 5). It is a way to start examining which values are prevalent in society and support the pupils to gain a critical understanding of themselves and their social, cultural and historical context. This will, in turn, pave way for questions of what really matters in life. For these particular teachers, this is considered as an expression for how they focus on "solidarity" (Teacher 5), "reciprocity" and "a sense of justice and empathy" as a part of "the normative guidelines" which "unite all religions" (Teacher 1, Teacher 5).

The approach, which these teacher express in their answers, does not exclude an introduction of ethical theories considered as analytical tools. One teacher explains how he tries to teach the pupils normative ethical theories and their 
respective focus on character, actions and consequences (Teacher 1). Another teacher emphasizes that normative ethical theories can provide analytical tools which can be helpful to identify different lines of argument (Teacher 5). At the same time, it is important not to use theories in order to endorse in "intellectual games" but rather to understand what other people think is right (Teacher 5). It is possible to interpret this way to treat moral issues together with the pupils as an inclusive perspective; in this case, characterized by an attention to others as human beings which can evoke compassion or sympathy that contributes to our moral awareness and autonomy.

\section{Discussion}

In the introduction it was pointed out that teachers have conflicting responsibilities, to convey values and facilitate critical thinking, which has often been considered a theoretical problem and the discussion has concerned theoretical solutions (e.g., Peters, 1998, pp. 38-39; Gardener, 1981; Gardener, 1985; O'Hear, 1998). The overall aim of this paper has been to draw attention to the conflicting responsibilities as a practical problem that teachers face and are expected to solve in their pedagogical practices and consequently make an empirically informed contribution to this debate.

The results indicate that the RE teachers who participated in the study made different judgements on how to balance their roles, as conveyers of values and facilitators of critical thinking, with the corresponding conflicting educational aims, that the pupils should become eligible democratic citizens and independent rational individuals. It is important to emphasize that even if all teachers expressed that moral education is an essential part of the subject religious education, they described their priorities in different ways. An interpretation of the results is that the teachers preferred different solutions to the problem depending on what they regarded to be the principal aim of moral education in a way that reflects the philosophical debate, and their respective answers can accordingly be labelled character-based, reason-based, and integrative approaches to moral education.

In the Swedish school system, however, RE teachers have been considered to have a special responsibility for moral education, including conveying values and facilitating critical thinking (SNAE, 2011). Their priorities are not only an expression of individual preferences but have to be put in relation to the regulatory documents of the school system as such. The task of fostering democratic citizens is, for instance, stated in the Swedish Education Act $(2010: 800,4$ §) and further elaborated in the Curriculum for the upper secondary school under the heading "fundamental values" (SNAE, 2013, p. 4). It is only in the syllabus for RE that the task to facilitate the ability to "use ethical concepts, ethical theories and models" as well as exercise "critical thinking" is introduced (SNAE, 2011, p. 137).

If the regulatory documents are interpreted as a hierarchy, the Education Act takes precedence over the Curriculum for the upper secondary school and the syllabus for religious education, which means that the teachers' primary responsibility is to convey a set of democratic values. This seems to be the position 
of the teachers in this study that choose to embrace a character-based approach to moral education. They express an interest to lead by example, convey values, and facilitate the pupils' self-understanding in a social, cultural and historical context. An interpretation would be that these teachers emphasize the task of conveying values at the expense of a critical assessment of ideals, norms and values.

The teachers in this study who choose to embrace a reason-based approach to moral education was of another opinion and articulated that they wanted to focus on facilitating critical examination of ideals, norms and values. From this point of view, the special responsibility RE teachers have for moral education in the Swedish school system, is stated in the syllabus as facilitating the pupils' ability to "use ethical concepts, ethical theories and models" as well as exercise "critical thinking". The teachers express that they wanted to challenge the pupils with dilemmas and aimed to assess everything critically in order to enable their development into autonomous and responsible adults. An interpretation would be that these teachers emphasize the task of critical assessment at the expense of conveying ideals, norms and values.

The teachers in this study who choose to embrace an integrated approach to moral education articulated a more pronounced ambition to balance the tasks to convey values and facilitate critical thinking in their pedagogical practices. An interpretation is that the teachers' use of art and authentic examples enables the pupils to let go of their self-centredness and develop a deeper understanding of themselves and other people in a social, historical and cultural context. It is important to convey certain values, e.g., "solidarity", "reciprocity" and "a feeling of justice and empathy", in order to be able to critically assess different kinds of secular and religious normative guidelines. In this way they explicitly try to balance the sometimes conflicting tasks of conveying and critically assessing values.

The different approaches to moral education provide important tools to interpret how teachers choose to manage the conflicting responsibilities, to convey values and to facilitate critical thinking, in their pedagogical practices. As we have seen, there are reasons to embrace any of these approaches to moral education, as each of them are compatible with various interpretations of the conflicting responsibilities, which are stated in the regulatory documents. A somewhat simplified description would be that the character based and reason based approach solves the paradox of moral education by emphasizing either the responsibility to convey values or the responsibility to facilitate critical thinking. The integrated approach is the only of these alternatives that provides a more pronounced way to address the difficulties of balancing both of these responsibilities. By addressing the paradox of moral education as a practical problem that teachers face and are expected to solve in their pedagogical practices we want to emphasize the urgency of this issue. Since there are no official guidelines of how to interpret which of these responsibilities should be given priority in any specific situation, it is important to raise the awareness of this problem.

As we have seen throughout this paper it is not obvious how to relate to the conflicting responsibilities of conveying values and facilitating critical thinking. Nevertheless, two main alternatives come to mind: either that the fundamental 
values stated in the curriculum are discharged from any assessment, or to trust that these values can withstand thorough critical examination. Since the fundamental values of the curriculum are contingent and subject to political decisions, moral education can appear to be authoritarian and a source of indoctrination, in an educational system. Therefore, it is important that an educational system, built on a set of democratic values, can and will be subject to critical assessment. In this context, we believe that it is important that a critical examination is based on an understanding of ideals, norms and values and performed with appropriate analytical tools. If teachers let their pupils exercise critical thinking, they may develop a deeper understanding of the fundamental values, which can influence their convictions. Of the alternatives that have been subject of this study, the integrative approach to moral education seems to be the most apt candidate. As RE teachers have been considered to have a special responsibility for moral education in the Swedish school system, it seems to be of particular importance that they not only convey a set of democratic values but also fulfil the task of facilitating critical thinking and trust that the values hold - or otherwise endorse work for change within that framework.

\section{Conclusion}

In the beginning of this paper moral education was presented as an example of a controversial issue which has caused extensive debate in a contested area of philosophy (see Hirst \& White, 1998, p. 2). This study indicates that the RE teachers who participated were balancing their roles, as conveyers of value and facilitators of critical thinking, in a way that reflects the theoretical debate. Their answers can be categorized as character-based, reason-based, and integrative approaches to moral education. This points towards the conclusion that moral education also can be considered as a controversial issue in a more practical sense. This is something which has not been accounted for in the previous debate. In this study we have argued for a practical solution of how to balance the conflicting responsibilities, and hence of the paradox of moral education in that respect.

\section{References}

Almén, E., Furenhed, R., Hartman, S. G., \& Skogar, B. (2000). Livstolkning och Värdegrund: Att Undervisa om Religion, Livsfrågor och Etik (Life Interpretation and Fundamental Values: To Teach about Religion, Existential Questions and Ethics). Linköpings Universitet: Linköping.

Aristotle (1977). Politics. Cambridge, Mass.: Harvard University Press.

Aristotle (1982). The Nicomachean Ethics. Cambridge, Mass.: Harvard University Press. Bryman, A. (2008). Social Research Methods. Oxford: Oxford University Press.

Bullough Jr., R. V. (2011). Ethical and Moral Matters in Teaching and Teacher Education. Teaching and Teacher Education, 27(1), 21-28.

Campbell, E. (2013). The Virtuous, Wise, and Knowledgeable Teacher: Living the Good Life as a Professional Practitioner. Educational Theory, 63(4), 413-429. 
Carr, D. (1983). Three Approaches to Moral Education. Educational Philosophy and Theory, 15(2), 39-51.

Carr, D. (1996). After Kohlberg: Some Implications of an Ethics of Virtue for the Theory of Moral Education and Development. Studies in Philosophy and Education, 15(4), 353-370.

Carr, D. (2007). Character in Teaching. British Journal of Educational Studies, 55(4), 369389.

Carr, D. (2015). The Paradox of Gratitude. British Journal of Educational Studies, 63(4), 429-446.

Carr, D., \& Steutel, J. (1999). The Virtue Approach to Moral Education. In D. Carr \& J. Steutel (Eds.), Virtue Ethics and Moral Education. London: Routledge.

Curren, R. (2010). Aristotle's Educational Politics and the Aristotelian Renaissance in Philosophy of Education. Oxford Review of Education, 36(5), 543-559.

Curren, R. (2014). Motivational Aspects of Moral Learning and Progress. Journal of Moral Education, 43(4), 484-499

Frank, O. \& Löfstedt, M. (2015). Etikdidaktik - Grundbok om Etikundervisning i Teori och Praktik (Ethics Didactics - Textbook in Ethics Education in Theory and Practice). Lund: Studentlitteratur.

Gardner, P. (1981). On Some Paradoxes in Moral Education. Journal of Philosophy of Education, 15(1), 65-76.

Gardner, P. (1985). The Paradox of Moral Education: A Reassessment. Journal of Philosophy of Education, 19(1), 39-48.

Hand, M. (2014). Towards a Theory of Moral Education. Journal of Philosophy of Education, 48(4), 519-532.

Hansen, D. T. (2001). Teaching as a Moral Activity. In V. Richardson (ed.), Handbook of Research on Teaching. Washington, D.C.: American Educational Research Association.

Hartman, S. G. (2008). Om Skolans Religionsundervisning, Synen på Eleven och de Didaktiska Frågorna - Några Reflektioner (On Religious Education in School, Some Reflections on the Pupil and the Didactical Questions). Didaktikens Forum, 5(3), 72 84.

Haydon, G. (2010). Reason and Virtues: The Paradox of R. S. Peters on Moral Education. Journal of Philosophy of Education, 43(S1), 173-188.

Hirst, P. H., \& White, P. (Eds.) (1998). Philosophy of Education: Major Themes in the Analytic Tradition. Volume 4, Problems of Educational Content and Practices. London: Routledge.

Jackson, P. W., Boostrom, R. E., \& Hansen, D. T. (1993). The Moral Life of Schools. San Francisco: Jossey-Bass.

Kohlberg, L. (1966). Moral Education in the Schools: A Developmental View. The School Review, 74(1), 1-30.

Kristjánsson, K. (2006). Habituated Reason - Aristotle and the 'Paradox of Moral Education'. Theory and Research in Education, 4(1), 101-122. Los Angeles: SAGE Publications Ltd.

Kristjánsson, K. (2015). Aristotelian Character Education. London: Routledge.

Kvale, S. (2007). Qualitative Research Kit: Doing Interviews. London: SAGE Publications Ltd.

Larsson, R. (2009). Samtal vid Brunnar - Introduktion till religionspedagogikens Teori och Didaktik (Conversations by Wells - Introduction to the Theory and Didactics of Religious Pedagogy). Lund: Arcus.

Murdoch, I. (2001). The Sovereignty of Good. London: Routledge. 
Nussbaum, M. C. (1992). Love's Knowledge. Essays on Philosophy and Literature. Oxford: Oxford University Press.

O'Hear, A. (1998). Moral Education. In P. H. Hirst \& P. White (eds.), Philosophy of Education: Major Themes in the Analytic Tradition. Volume 4, Problems of Educational Content and Practices. London: Routledge.

Peters, R. S. (1998). Reason and Habit: The Paradox of Moral Education. In P. H. Hirst \& P. White (eds.), Philosophy of Education: Major Themes in the Analytic Tradition. Volume 4, Problems of Educational Content and Practices. London: Routledge.

Surprenant, C. W. (2010). Kant's Contribution to Moral Education: The Relevance of Catechistics. Journal of Moral Education, 39(2), 165-174.

Swedish Education Act (2010). Education Act - SFS 2010:800. Stockholm: Ministry of Justice.

Swedish Research Council - SRC (2017). Good Research Practice. Stockholm: Swedish Research Council.

Taylor, M. R. (1982). Character and Autonomy: The Paradox of Moral Education. ProQuest Dissertations \& Theses Global.

The Swedish National Agency for Education - SNAE (2011). Läroplan, Examensmål och Gymnasiegemensamma Ämnen för Gymnasieskola 2011 (Curriculum, Examination Goals and Common Subjects for the Upper Secondary School 2011). Stockholm: Skolverket.

The Swedish National Agency for Education - SNAE (2013). Curriculum for the Upper Secondary School. Stockholm: Skolverket.

Yin, Robert K. (1994). Case Study Research - Design and Methods. $2^{\text {nd }}$ Edition. London: SAGE Publications Ltd. 
